\title{
Unusual manifestation of acute retrocecal appendicitis: pericholecystic fluid
}

\author{
Akut retroçekal apandisitin sıra dışı bulgusu: Perikolesistik sıvı
}

\author{
Oktay ALGIN, Evrim ÖZMEN, Ayşenur Şirin ÖZCAN, \\ Şehnaz ERKEKEL, Mustafa KARAOĞLANOĞLU
}

\begin{abstract}
Subhepatic-retrocecal appendicitis is a rare entity in which the diagnosis is challenging. In patients presenting with right abdominal pain with atypical clinical, laboratory and ultrasound (US) findings, acute appendicitis should be eliminated with computed tomography (CT). Multi-detector CT (MDCT) can be used effectively for the diagnosis of retrocecal appendicitis without additional preparation or focused examination. Here, we present a patient with acute subhepatic-retrocecal appendicitis in whom the clinical and US findings mimicked acute cholecystitis. To the best of our knowledge, there is no previous report related to acute appendicitis presented only with pericholecystic fluid that could be diagnosed with MDCT. Retrocecal-subhepatic appendicitis is a rare condition that might present with atypical clinical, laboratory and radiological signs. US is usually insufficient for the definitive diagnosis. In this situation, MDCT could be a rapid and efficient tool for localizing the appendix and for the differential diagnosis.
\end{abstract}

Key Words: Computed tomography; retrocecal appendicitis; ultrasonography; upper abdominal pain.
Subhepatik alana uzanan retroçekal yerleşimli apandisit, nadir bir durumdur ve tanısı oldukça zordur. Karın ağrısı ile başvuran ve atipik klinik, laboratuvar ve ultrasonografi (USG) bulguları olan hastalarda akut apandisit bilgisayarlı tomografi (BT) ile ekarte edilmelidir. Çok detektörlü BT (ÇDBT) ile retroçekal apandisit tanısı, ek bir hazırlığa gerek kalmaksızın konulabilir. Bu yazıda, klinik ve USG bulguları akut kolesistiti taklit eden ve ÇDBT ile tanı konulan subhepatik-retroçekal yerleşimli akut apandisit olgusu sunuldu. Bizim bilgimize göre literatürde yalnızca perikolesistik sıvı izlenmesi ile şüphelenilen ve ÇDBT ile tanı konulan, akut retroçekal yerleşimli apandisit olgusu bulunmamaktadır. Subhepatik-retroçekal apandisit oldukça nadir bir durumdur ve atipik klinik, labaratuvar ve radyolojik bulgularla karşımıza çıkabilir. Ultrasonografi tanı konulmasında sıklıkla yetersizdir. Bu durumda ÇDBT, hızlı ve etkin bir tanı aracı olarak kullanılabilir.

Anahtar Sözcükler: Bilgisayarlı tomografi; retroçekal apandisit; ultrasonografi; üst kadran ağrısı.
Acute appendicitis is the most common surgical and radiological abdominal emergency in the western world, occurring in $7-12 \%$ of the general population. [1] The location and extent of the inflammatory processes of acute appendicitis may vary depending on the location of the appendix. ${ }^{[2]}$ When the appendix is in the retrocecal position, the signs and symptoms of acute appendicitis might be atypical and could mimic right flank and hypochondriac pathologies including acute cholecystitis, diverticulitis, acute gastroenteritis, ureteral colic, acute pyelonephritis, intestinal neopla- sia, and irritable bowel syndrome. ${ }^{[3]}$ Rapid and precise diagnosis could reduce the morbidity and mortality of acute appendicitis. ${ }^{[1]}$

Here, we present a case of acute subhepatic-retrocecal appendicitis, in whom clinical and sonographic findings mimicked acute cholecystitis. In the ultrasound (US) examination, the only pathologic finding was pericholecystic fluid. In the multi-detector computed tomography (MDCT) examination, we noticed a retrocecal inflamed appendix, which extended to the 
pericholecystic-subhepatic area. To our knowledge, there has been no reported acute appendicitis case who presented only with pericholecystic fluid and was later definitively diagnosed with MDCT. We think that this case report could be useful for the rapid and precise diagnosis of similar cases.

\section{CASE REPORT}

A 38-year-old male presented with right hypochondriac pain lasting for 6 hours. There was no significant finding in his medical history or on chest and abdominal roentgenograms. In his physical and laboratory examination, Murphy's sign was positive and leukocytosis was detected. Therefore, abdominal US examination was performed with a pre-diagnosis of acute cholecystitis; there was no abnormal finding except pericholecystic fluid. For the differential diagnosis, MDCT was performed under emergent conditions without preparation. In intravenous contrast-material enhanced MDCT, the appendix was situated in the retrocecal region with an increased diameter of $2 \mathrm{~cm}$. Appendicular wall thickening was observed as well. In multiplanar reformatted images, retrocolic-pericecal inflammation along with an inflamed appendix extending to the subhepatic region was detected (Fig. 1). Moreover, in MDCT, pericholecystic fluid and appendicolith with a diameter of $8 \mathrm{~mm}$ in the proximal portion of the appendix were detected (Fig. 2). No other pathologic finding was observed in MDCT.

The patient was diagnosed as acute retrocecal appendicitis and operated based on these findings. Acute appendicitis was confirmed with surgery, and the patient healed without complication. The histologic examination was reported as perforated acute appendicitis.

\section{DISCUSSION}

Acute appendicitis is one of the most common surgical abdominal emergencies. ${ }^{[4]}$ Early diagnosis and treatment could reduce the mortality and morbidity of acute appendicitis significantly. ${ }^{[5]}$ The most common position of the appendix is intraperitoneal, and the second is in the retrocecal region. ${ }^{[3,6]}$ More than $50 \%$ of the patients with retrocecal appendicitis can present with atypical findings. ${ }^{[2]}$ This condition could even mimic acute cholecystitis or gallbladder perforation. ${ }^{[3,7]}$

Although US should be the first-line choice in the diagnosis of acute appendicitis, it might be inadequate in retrocecal appendicitis. ${ }^{[4]}$ Moreover, as US is a rapid technique and it is significantly operator-dependent, ${ }^{[4]}$ MDCT could be useful in such patients. An increased appendiceal diameter $(>6 \mathrm{~mm})$, pericecal-retrocolic inflammation, and the presence of an appendicolith are diagnostic for acute retrocecal appendicitis. ${ }^{[5,8]}$ As in our patient, MDCT was helpful in the evaluation of

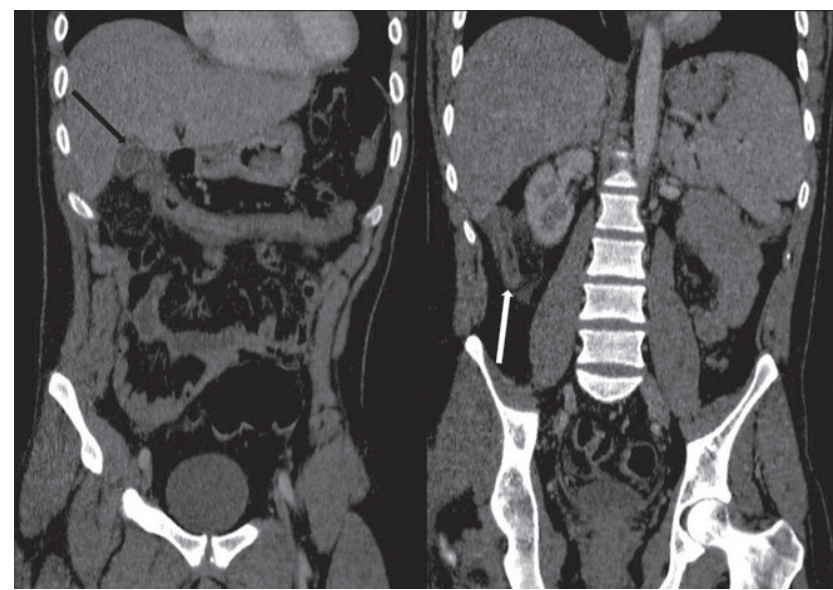

Fig. 1. Coronal reformatted MDCT images of the patient. Morphology of the appendix (white arrow, right image), pericholecystic fluid (black arrow, left image) and periappendiceal inflammation are clearly seen in the reformatted images.

the periappendiceal-pericecal region and could demonstrate the appendix in high resolution. On the other hand, US examination is not optimal in patients with obesity and excessive bowel gases. CT is a diagnostic method for such patients. ${ }^{[9]}$

Technical details of the CT examination, in patients pre-diagnosed with acute appendicitis, are controversial. Various CT techniques have been described for diagnosing acute appendicitis, including intravenous contrast-material enhanced CT with or without orally and/or rectally administered colon contrast material, and they have a high diagnostic accuracy. ${ }^{[8]}$ Some authors suggest that a non-contrast examination would be sufficient. ${ }^{[1,9]}$ In such cases in our department, we perform MDCT examination after administration of oral and intravenous contrast material. However, in the presented patient, we could not give oral contrast

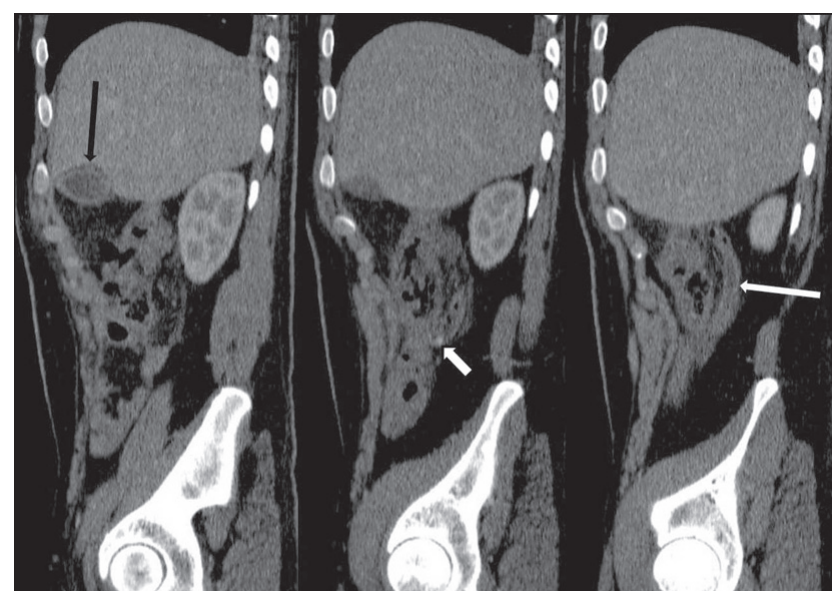

Fig. 2. Sequential sagittal reformatted MDCT images. Morphology of the appendix (long white arrow), pericholecystic fluid (black arrow), periappendiceal inflammation, and appendicolith (short white arrow) are clearly seen in the reformatted images. 
since the patient had nausea and vomiting. According to the findings detected in the MDCT examination, we understand that MDCT without oral and rectal contrast media is a valuable and accurate method in the diagnosis of appendicitis and can be an effective diagnostic tool when the sonographic results are inadequate. ${ }^{[1]}$

In conclusion, acute appendicitis may present with various atypical clinical signs. Patients with retrocecal appendicitis may present only with minimal pericholecystic fluid as well. In such cases, when the appendix cannot be seen clearly or seems in an unusual localization, MDCT can be a useful method for establishing the correct diagnosis. Furthermore, the radiologist's diagnostic confidence appears greater with MDCT.

Conflict-of-interest issues regarding the authorship or article: None declared.

\section{REFERENCES}

1. Chalazonitis AN, Tzovara I, Sammouti E, Ptohis N, Sotiropoulou E, Protoppapa E, et al. CT in appendicitis. Diagn Interv Radiol 2008;14:19-25.

2. Kim S, Lim HK, Lee JY, Lee J, Kim MJ, Lee AS. Ascending retrocecal appendicitis: clinical and computed tomographic findings. J Comput Assist Tomogr 2006;30:772-6.

3. Ong EM, Venkatesh SK. Ascending retrocecal appendicitis presenting with right upper abdominal pain: utility of computed tomography. World J Gastroenterol 2009;15:3576-9.

4. Buluş H, Coşkun A. Subhepatik appendisit. Kolon Rektum Hast Derg 2010;20:29-32.

5. van Randen A, Laméris W, van Es HW, ten Hove W, Bouma WH, van Leeuwen MS, et al. Profiles of US and CT imaging features with a high probability of appendicitis. Eur Radiol 2010;20:1657-66.

6. Peletti AB, Baldisserotto M. Optimizing US examination to detect the normal and abnormal appendix in children. Pediatr Radiol 2006;36:1171-6.

7. Algin O, Ozlem N, Kilic E, Karaoglanoglu M, Arslan H. Gd-BOPTA-enhanced MR cholangiography findings in gall bladder perforation. Emerg Radiol 2010;17:487-91.

8. Yeung KW, Chang MS, Hsiao CP. Evaluation of perforated and nonperforated appendicitis with CT. Clin Imaging 2004;28:422-7.

9. Cağlayan K, Günerhan Y, Koç A, Uzun MA, Altınlı E, Köksal N. The role of computerized tomography in the diagnosis of acute appendicitis in patients with negative ultrasonography findings and a low Alvarado score. Ulus Travma Acil Cerrahi Derg 2010;16:445-8. 